\title{
SHIFTING CULTIVATION IN NORTH-EAST REGION
}

\author{
Bhaskar J Barthakur*
}

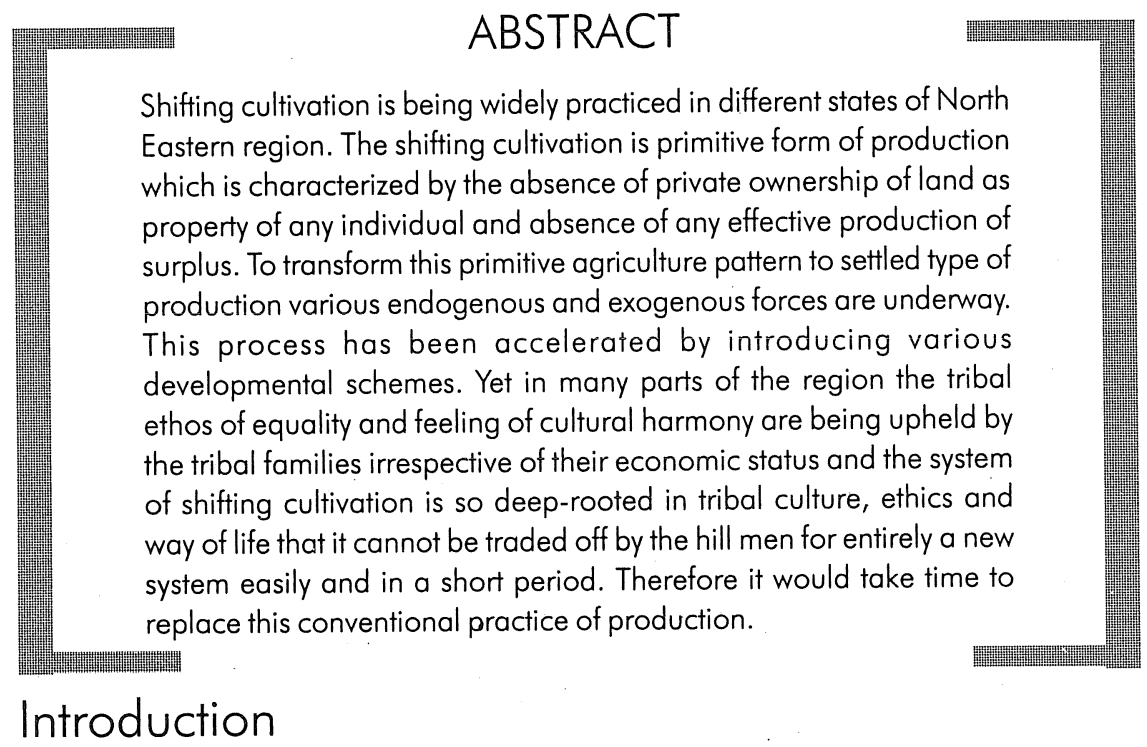

Shifting cultivation is primitive method of cultivation that might have originated at the Neolithic period between 13000 to 3000 B.C.' It may be the first method to use the soil for the production of crops. The hill inhabitants of Black Africa and America

* Dept. of Economics, St Claret College, Ziro, AP 
practiced this system of cultivation over a long period of time as a regular system. In the remote parts of Sweden, this system of cultivation was followed until 1920. In the middle of the last century; Europeans in Brazil and English settlers of seventeenth century in Virginia of the U.S.A. also practiced this shiffing cultivation. ${ }^{2}$ In India, shifting cultivation is still being practiced in the hill areas of Northeastern region, Bihar, Orissa, Andhra Pradesh, Madhya Pradesh, Tamil Nadu, Kerala, Karnataka and Maharashtra.

Shifting cultivation is known as slash-and-burn agriculture, migratory primitive agriculture, nomadic agriculture, hoe and burn, forest field rotation, land rotating agriculture and in Northeast India it is known as "ihum cultivation" or "jhumming". Due to diminution of fertility, "ihummians" have to shift from one area to another and thus it is known as shifting cultivation.

\section{The Process}

The process of shifting cultivation is peculiar in nature. The very first attempt is to select a plot. The next step is to slash the forest, bushes etc. up to stamp level in the month of December, January followed by drying and burning the jungle for making it clear. After that, with the help of simple instrumenis like dibble or digging sticks, holes are made on land for sowing seeds of several crops and on land for sowing are applied into the holes for getting a large variety of crops from the same field. After proper weeding by women and children, harvesting, threshing and storing, merry making and fallowing are the next steps to be followed.

Each jhum plot needs constant watching to protect the crops from damage from wild animals and birds. For this purpose a hut is constructed on the jhum site as the watch house where the jhumia and his wife live for the required period of time. ${ }^{3}$

The model of shifting cultivation represents the primitive mode of production which is characterized by the absence of private ownership of land as property of any individual. The access means the right to use the unit or units of resource for productive purpose without having any right to transfer any unit to any one else. The other crucial characteristic is the absence of effective production of surplus. Therefore there was no accumulation of surplus leading to capital formation and investment thereof in production for raising productivity and output (or income) per unit of labour. ${ }^{4}$

The original fertility of land along with the burnt ashes make it possible to raise a good yield of crops for a year or two, in this process of cultivation. After that all the nutrients of the soil becomes exhausted and thus yields fall drastically. This will 
force the farmers to shift into a new area leaving the previous land as fallow land for gaining fertility and follow the same process of 'slash and burn' in that new area. Again after one or two years farmers return to the first area of cultivation.

\section{Jhum Cycle}

In shifting cultivation, cultivation in a particular area for one or two years and then moving into another areas and again returning to the first area of cultivation completes a cycle. Thus, the number of years between two consecutive jhum operations constitutes a 'jhum cycle'. The cycle includes the number of years an area is under cultivation plus the years the area is kept under forest fallow. Previously, the fallow period was of 30 years and at present due to high pressure of population and heavy erosion of soil this fallow period has declined to 4 to 9 years or even less in different states of our country. Among the Northeastern states, Meghalaya and Nagaland are having the longest jhum cycle of 9 years. Followed by Tripura- 8 years, Mikir hills of Assam-7 years, Manipur- 6 years and the states like Mizoram and Arunachal Pradesh are having the lowest jhum cycle of 3 to 4 years.

\section{Area under Shifting Cultivation}

Shiffing cultivation requires a large amount of land but it can support only a small number of populations. About the extent of shifting cultivation in terms of area or in terms of number of persons engaged in it there is no definite reliable information. As per old Indian Council of Agricultural Research (ICAR) review the total estimated area under shifting cultivation was 5.42 lakh hectares and about 26,441-lakh tribal populations were engaged in it.

The Dhebar Commission revealed that nearly 5.41 lakh hectares of area are covered per year by the shifting cultivation and about 25.89-lakh tribal populations are depending on it. Again as per the estimates of Vidyarthi, about 2.6 million tribal people are engaged in shifting cultivation covering nearly 135 million areas of land scattered in different parts of India. ${ }^{5}$

In the North-eastern region, the estimates framed by the state departments of the region in 1974 reveals that shifting cultivation is prevalent in nearly $2.4 \%$ of the total area of the entire North-eastern region at a point of time. About 2.7 million hectares of area of the region is at present available for shifting cultivation and out of which about 4.3 lakh hectares of the area is cultivated at one point of time leaving the rest area for natural regenerations of fertility. Further, about 4.25 lakh tribal families of the entire region are found engaged in shifting cultivation and total area cultivated per tribal family in the region is 1.07 hectares. $^{6}$ 
As per recent estimate it is found that total area under shifting cultivation in a year in all North-eastern states is nearly 4.16 lakh hectares in comparison to that of 9089 lakh hectares of area in whole India. Again nearly 2.8 million hectares of land is at present available for shifting cultivation in the North-eastern region in comparison to those of 6.75 million hectares of land in the whole country. About 5.47 lakh tribal families of North-eastern region are involved in the shiffing cultivation.

The Task Force Report on Shifting Cultivation of North-eastern Region, Ministry of Agriculture, Government of India, published in 1990 reveals that the annual area under shifting cultivation in the entire region is 3,865 sq. k.m. which is nearly $1.5 \%$ of the total geographical area of the region. Again the annual area covers under shiffing cultivation in various North-eastern states are $900 \mathrm{k.m}$. in Manipur, 700 k.m. in Arunachal Pradesh, 696 k.m. in Assam, 530 k.m. in Meghalaya, 630 k.m. in Mizoram, 190 k.m. in Nagaland and 223 k.m. in Tripura.

Table1. Shifting Cultivation in NER

\begin{tabular}{|c|c|c|c|c|c|c|c|}
\hline State & $\begin{array}{c}\text { Total } \\
\text { area } \\
\text { Sq.km. }\end{array}$ & $\begin{array}{l}\text { Annual } \\
\text { area } \\
\text { under } \\
\text { s.c. } \\
\text { sq.km. }\end{array}$ & $\begin{array}{l}\text { Fallow } \\
\text { period } \\
\text { (years) }\end{array}$ & $\begin{array}{c}\text { Minimum } \\
\text { area } \\
\text { under s.c } \\
\text { at one } \\
\text { time or } \\
\text { another } \\
\text { (sq.km.) }\end{array}$ & $\begin{array}{c}\text { Proportion } \\
\text { of total } \\
\text { area (\%) }\end{array}$ & $\begin{array}{c}\text { No of } \\
\text { families } \\
\text { practicing } \\
\text { s.c. }\end{array}$ & $\begin{array}{c}\text { Average } \\
\text { area } \\
\text { per } \\
\text { (hectares) }\end{array}$ \\
\hline 1 & 2 & 3 & 4 & 5 & 6 & 7 & 8 \\
\hline $\begin{array}{l}\text { Arunachal } \\
\text { Pradesh }\end{array}$ & 83,743 & 700 & $3-10$ & 2.100 & 2.5 & 54,000 & 1.3 \\
\hline Assam & 78,438 & 696 & $2-10$ & 1,392 & 1.8 & 58,000 & 1.2 \\
\hline Manipur & 22,327 & 900 & $4-7$ & 3,600 & 16.1 & 70,000 & 1.3 \\
\hline Meghalaya & 22,429 & 530 & $5-7$ & 2,650 & 11.8 & 52,290 & 1.0 \\
\hline Mizoram & 21,429 & 630 & $3-4$ & 1,890 & 8.9 & 50,000 & 1.3 \\
\hline Nagaland & 16,579 & 190 & $5-8$ & 1,913 & 11.5 & $1,16,046$ & 0.9 \\
\hline Tripura & 10,486 & 223 & $5-9$ & 1,115 & 10.6 & 43,000 & 0.5 \\
\hline
\end{tabular}

Source: Task Force Report on Shifting Cultivation, Ministry of Agriculture (1983), as quoted in Basic Statistics of NER, 1990, Shillong, p.24 
The report further shows that about 4.43 lakh families of the entire North eastern region were practicing shifting cultivation at that point. Moreover, the statewise break-up shows that the number of families practicing shifting cultivation were 1.16 lakh in Nagaland, 70,000 in Manipur, 58,000 in Assam, 54,000 in Arunachal Pradesh, 52,090 in Meghalaya, 50,000 in Mizoram and 43,000 in Tripura.

\section{Cropping Pattern}

In shifting or jhum cultivation tribal farmers follow a mixed land use pattern raising various crops together. Thus, they produce large variety of crops from the same field and these include food grains, vegetables and cash crops. The most common crop of "ihummians" is high land paddy or jhum paddy which they produce along with maize, fox-tail millet, finger millet, bean, tapioca, yam, sweet potato, ginger, tobacco, sea sum, chillies and leafy vegetables.

\section{Advantages}

The main advantage of the shifting cultivation to the hill people is that it provides a very easy method for the preparation of land for cultivation. Weeds and bushes can be cleared easily by slash and burn process and within a shortest possible period crops can be produced and harvested. In this system, there is no danger from either flood or drought. The mountain streams provides regular water supply for cultivation at moderate rate.

\section{Evil Effects}

The most important evil effect of shifting cultivation is that destruction of forest in the hill areas causes heavy soil erosion during rainfall and consequent salutation in the major rivers like Brahmaputra and Barak leading to a heavy flood in the plain low-lying areas. Moreover loss of topsoil in the hill areas to the extent of $22 \%$ of the total soil due to "ihumming" causes a serious fall in the fertility of the soil and thus it creates a serious economic problem for the tribal people.

The second evil effect of jhumming is that as there is no private ownership of land thus the farmers do not undertake any measure for soil conservation and improvement.

Thirdly, shifting cultivation causes deforestation on a large scale and is highly destructive to productive and protective values of forests.

Fourthly, shifting cultivation causes a high national waste as it converts a green land into fallow land for the major part of the jhum cycle.

Lastly, shifting cultivation upsets the ecological balance of nature. 


\section{Extent of Destruction of forest in North-east region}

A recent report released by the Dehradun based Forest survey of India (FSI) based on satellite data and extensive field survey shows Assam to be the main victim of shifting cultivation in the recent years. In the early 1990's, the state lost about 243 sq k.m. of forests for shifting cultivation. In the same period, jhumming further deforested 100 sq. k.m. in Meghalaya, 28 sq k.m. in Arunachal Pradesh and Manipur and $10 \mathrm{sq} \mathrm{k.m.} \mathrm{in} \mathrm{Tripura.}$

In the past, the gap between successive jhumming cycles used to be around 25 years, giving enough time for the forests and soil to regenerate. But, in present days, the period is shortened to a few years and thus regenerating become impossible.

Renewed cultivation has permanently rendered the land waste. Studies show that the topsoil loss in the jhumming mode of cultivation is 40 tones per hectare, compared to a mere 3 tones per hectares in conventional farming. Further, severe soil erosion on the hilltops and catchment areas cause silting of reservoirs and streams below.

As for example, in Meghalaya, unabated jhumming has turned the once thick evergreen forest belt in Cherrapunii, a place that used to record the highest rainfall in the World, into dry brown scar. The jhumming practice has caused extensive climatic changes in the state and destroyed rare flora and fauna.

\section{Environmental Imbalance}

Furthermore, it is widely believed that this shifting cultivation leads to environmental degradation and disturbs fragile eco-system. This occurs as a result of the destruction caused by surrounding natural vegetation. In this way, thousands of valuable timbers and medicinal plants are lost every year. Soil erosion results in gradual exhaustion of the other surface of the soil due to lack of any shielding measures. Due to the short period of jhumming cycle and hasty population growth in the last two decades, the hill slops are severely disturbed by the growth of villages and their practices, which is also leading to the problem of soil erosion. As a result, the environmental imbalance has resulted uneven spread of monsoon rainfall leading to the problem of draught and excessive rainfall resulting flood in this region.

\section{Efforts and Strategies}

In the intervening time, Government and other agencies have undertaken various measures for controlling shifting cultivation in desired direction. The measures undertaken: 


\section{Watershed management}

During the Sixth plan, the North Eastern Council (NEC) had introduced a concept of watershed management on pilot basis for optimum use of land and water resources within a phsoigraphic or hydrological unit governed by natural conditions. This watershed management makes provision for scientific survey and investigation of each unit for detailed planning and its implementation conducted by a technical team on each sub watershed. The technical team provides guidelines to each sub watershed on soil and land capability, design, cropping patterns, cost estimates, economic analysis etc. North Eastern Council (NEC) is also helping these units and encouraging other units to develop in the catchment area of major rivers.

Watershed management is now becoming very much popular in some North Eastern states. The National Watershed Development project for rain fed areas is now being implemented in eight of the thirty-four blocks in Meghalaya during 1996-97. The centrally sponsored scheme includes soil and water conservation, innovation for mixed cropping, development of horticulture, animal husbandry, pisciculture, household production system and management of common property resources. The Government of India sanctioned one model watershed management project at Pynthelyndden in Mairang block in 1990-91 and subsequently seven more projects were sanctioned.

The total amount earmarked for these projects in Meghalaya during the eight fiveyear plan was Rs. 2.25 crore and funding was done on the basis of $75 \%$ being contributed by the center and rest by the state Govt. The state's share had been given in the form of long-term loans by the center. In each of the eight projects, a cluster of villages had been identified covering an area of about 500 hectares. A composite nursery for forest and agriculture plantation had been set up in all the eight projects for meeting the demands of planting materials. In order to train the people in various income-generating activities, farmer's group had been set up in all projects areas. Since, the projects were put into practice in rainfed areas where about $40 \%$ land were under cultivation, the first stage was to harness the rain water. For this drains and small check dams had been constructed. They served as the source for irrigation as for fishery development.

In Tripura, under the same National Watershed Development Project, another Rs.3.60 crore centrally sponsored project was undertaken to cover an area of 7,205 hectares in Dhalai and North Tripura districts. Under this project a total of 1994 families, most of them below the poverty line in two Tripura districts were taken under consideration. 


\section{Settlement of Jhummians}

To stop jhumming completely it will require huge investment and many years. Thus, under this situation short-term measures should be undertaken to improve productivity and also to check soil erosion. ICAR has already suggested in this line. Considering the physiographic character of land, climatic conditions, social customs, food habits etc. this would require a system which includes agriculture, horticulture along with animal husbandry, fishery, poultry farming etc. Success of this alternative diversified farming depends upon the gaining of confidence of jhummias over this alternative system through persuasion, demonstration, and applied fundamental research to be conducted very slowly without any hurriedness.

\section{Soil conservation measures}

It is the need of the hour to protect the delicate eco-system, in order to protect biodiversity. This will benefit all sections of the people of hills and plains. In order to control jhum cultivation, public awareness is considered necessary to stimulate the people to adopt more environment friendly methods of cultivation.

To safeguard the eco-system, the Central Government has already taken steps to control jhum cultivation. The Planning Commission also has approved the revival of the scheme for control of shifting cultivation in North east region with 10\% central aid.

\section{Development of Rubber, Oil palm and Coffee cultivation}

In order to control shifting cultivation in the hill areas of North-east, result oriented steps must be taken to take up intensive and extensive rubber, coffee and oil palm cultivation in this region. In Assam, the state government in March $1997 \mathrm{had}$ decided that in large area of the non-forest wasteland would be brought under rubber block plantation scheme where the Rubber Board of India would contribute $65 \%$ of the total investment. In addition it had been decided to bring 5,000 hectares of land under 'robasta' variety of coffee cultivation in Assam. Another 1000 hectares of land in the Karbi-Anglong district had been earmarked for raising oil-palm cultivation.

Also in Tripura, the state Govt. and the Tripura Tribal Area Autonomous District Council (TTADC) had taken a joint initiative to rehabilitate 15,000 tribal families in rubber plantation scheme. The project was implemented in 1995-96. The target production of Rubber was fixed at 10,000 metric tones.

The National Bureau of Science Survey and Land Use Planning which have conducted a joint survey in the state of Tripura, finally observed that $1,00,000$ 
hectares of land could be brought under rubber plantation in the state that would also improve the fertility of land besides maintaining natural balance. Central Rubber Board, Planning Commission and World Bank, are aiding the project and Tripura Forest Development Plantation Corporation and Tripura Rehabilitation Plantation Corporation have been involved with the implementation project. The -World Bank has allocated Rs. 28 crore for the project. Besides plantation the state govt has set up 43 rubber processing centers in different parts of the state. An altogether 1966 family has been rehabilitated under the project.

\section{Reports and Field Study}

\section{National Environment Report:}

In environment report submitted by the Union Environment Ministry to the United Nations in 1992, has mentioned about the practice of jhum cultivation among the tribal people of the North-east. The report reasoned out why the old practice became unviable and damaging and also stated that the increasing population and decreasing availability of land and fall in the crop unplanted period in jhumming have affected the cultivation process, reducing the cycle to mere five years from more than 20 to 40 years in the past.

However, the study paper suggested that the new technologies considered obligatory to be explored and interim mechanism be applied before replacing the old organism, since report added, "changing practices is a slow process." The national paper also stressed out on alternative farming in the North-east. Setting example of terrace farming in the hilly region, the report noted that the department of Agriculture in Nagaland had identified experts who were said to have guided farmers in deferent parts of the state.

The Nagaland farmers adopt terrace method to go well with the hilly terrains by constructing terraces. The report explained, "During the monsoon, the fields are flooded. Rainwater is used for irrigation, channelised through indigenous bamboo conduits. Young rice plants are transplanted to the terraces, locally known as 'panikheti' from the nurseries".

\section{IFAD's Study}

The International Fund for Agricultural Development (IFAD), a United Nation's body based in Rome has undertaken an extensive study on Jhum cultivation practiced by tribal people of the North-eastern region. The study is intended to formulate a time-bound project for the tribal folks who are eking out a living on unsustainable slash and burn method of cultivation on hill slopes. The IFAD experts would also be working on projects suggesting 'alternative development' plans for jhumming 
including rehabilitation of the tribal families involved in the primitive farming practices.

The North-eastern Council (NEC) has also undertaken time-bound progamme to re-settle 16,500 families during the period 1978-92 from such traditional jhumming practices to settled cultivation.

\section{Appraisal}

Even though the state govts and a range of other agencies have already made a variety of attempts in weaning the North-east tribals into contemporary scientific cultivation but a good number of these endeavors have failed to realize desirable results.

A field study of Department of Sociological Anthropology of North Eastern Hill University, Shillong showed the tribals hardly used the subsidy given to them for starting a matured method of farming. In a number of cases, they sold the land allotted to them, and went back to their old life. The study pointed out that jhumming is an ancient socio-economic tradition that the tribal people like to cling to.

Field survey in the Garo Hills of Meghalaya shows that some areas selected for terrace cultivation as part of the anti-jhumming efforts were unsuitable for food crops. Seeds were not often supplied on time, leading to belated sowing and poor harvesting. The proper infrastructure facilities necessary in this connection are not provided in the resettlement of colonies.

Such half-hearted official endeavors will hardly bring to an end jhumming's silent march in the North-east. As a consequence, under the present state of affairs, more planning and endurance will be obligatory in helping the tribals to make the agonizing switch to developed agricultural continuation.

\section{Conclusion}

Jhum cultivation survives in the heart of the hill inhabitants of the North-east region. It will not be feasible to wean away this traditional age-old practice of cultivation completely, but the magnitude of their practice of this type of cultivation is being significantly reduced by diverting and motivating the hill people for accepting a permanent and settled method of cultivation. The need of the hour is to pay attention in this matter from the side of Government agencies, Non-GovernmentalOrganizations as well as wholehearted motivational process to transform this age-old tribal agricultural practice into a settled and developed farming practice. 


\section{End Notes:}

1. FAO Paper, Shifting Cultivation, Tropical Agriculture, Vol. 34, No. 3, 1957, p 160.

2. Gaurav, P., The Tropical World, London 1961, p. 25.

3. Ganguly J.B.; Economics of Transition from Shifting to Settled Cultivation, p-76.

4. Ibid; $\mathrm{p}-78$.

5. Agarwal, A.K., Economic problems of Planning in North-eastern India. p. 321.

6. Basic Statistics of NER, 1990, North Eastern Secretariat, Shillong, p. 24.

\section{References:}

\section{Books:}

1. Agarwala, A.N. and Singh, S.P., The Economic of Development, New York, 1963.

2. Baver, P.T., Economic Analysis and Policy in Under-developed countries.

3. Bose, Saradindu. Carrying Capacity of Land under Shifting Cultivation. Asiatic Society, Calcutta, 1969.

4. Colin Clark \& Margaret Haswell. The Economics of Subsistence Agriculture. Macmillan, 1964.

5. Dutt, Ruddar and Sundharam, K.P.M., Indian Economy, S.Chand \& Company, Delhi, 2003.

6. Guha, Dr. A, 'Socio-economic changes in agrarian Assam' in Trends of Socio-economic changes in India (Vol.7), Indian Institute of Advanced Study, Simla, 1960.

7. Hungya, P. Land Tenure System in the hills of Manipur: Land Relations in North-East India, People's Publishing House, New Delhi, 1987.

\section{Reports and Allied Publications:}

1 Central Stastical Organization: Stastical Abstract, India, 1985, 1990.

2. FAO Paper, Shifting Cultivation, Tropical Agriculture, Vol.34, No.3, 1957

3. Ministry of Food and Agriculture: Indian Agricultural Statistics (Annual), Relevant issues.

4. North Eastern Council: Basic Statistics of North-eastern Region, February 1990.

North-eastern region, Basic Information, 1983, 1991.

5. Planning Commission: Draft, Sixth Five-Year Plan. 